\title{
THE RENAISSANCE
}

\author{
EXCLUDING DRAMA
}




\section{GREAT WRITERS STUDENT LIBRARY}

1. The Beginnings to 1558

2. The Renaissance Excluding Drama

3. Renaissance Drama

4. Restoration and 18th-Century Prose and Poetry

Excluding Drama and the Novel

5. Restoration and 18th-Century Drama

6. The Romantic Period Excluding the Novel

7. The Victorian Period Excluding the Novel

8. The Novel to 1900

9. 20th-Century Poetry

10. 20th-Century Fiction

11. 20th-Century Drama

12. American Literature to 1900

13. 20th-Century American Literature

14. Commonwealth Literature

Editor: James Vinson

Associate Editor: D. L. Kirkpatrick 


\section{THE RENAISSANCE}

\section{EXCLUDING DRAMA}

INTRODUCTION BY

ELIZABETH STORY DONNO

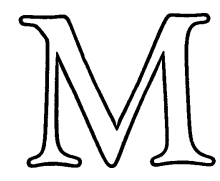


(C) The Macmillan Press Ltd, 1983

Softcover reprint of the hardcover 1st edition 1983

All rights reserved. No part of this publication may be reproduced or transmitted, in any form or by any means, without permission.

First published 1983 by

THE MACMILLAN PRESS LTD

London and Basingstoke

Associated Companies throughout the world

ISBN 978-0-333-28342-4 hard cover edition

The paperback edition of this book is sold subject to the condition that it shall not, by way of trade or otherwise, be lent, resold, hired out, or otherwise circulated without the publisher's prior consent in any form of binding or cover other than that in which it is published and without a similar condition including this condition being imposed on the subsequent purchaser.

ISBN 978-0-333-28343-1

ISBN 978-1-349-17058-6 (eBook)

DOI 10.1007/978-1-349-17058-6 


\section{CONTENTS}

EDITOR'S NOTE

INTRODUCTION

THE RENAISSANCE

NOTES ON CONTRIBUTORS page vii 1

19

191 


\section{EDITOR'S NOTE}

The entry for each writer consists of a biography, a complete list of his published books, a selected list of published bibliographies and critical studies on the writer, and a signed critical essay on his work.

In the biographies, details of education, military service, and marriage(s) are generally given before the usual chronological summary of the life of the writer; awards and honours are given last.

The Publications section is meant to include all book publications, though as a rule broadsheets, single sermons and lectures, minor pamphlets, exhibition catalogues, etc. are omitted. Under the heading Collections, we have listed the most recent collections of the complete works and those of individual genres (verse, plays, novels, stories, and letters); only those collections which have some editorial authority and were issued after the writer's death are listed; on-going editions are indicated by a dash after the date of publication; often a general selection from the writer's works or a selection from the works in the individual genres listed above is included.

Titles are given in modern spelling, though the essayists were allowed to use original spelling for titles and quotations; often the titles are "short." The date given is that of the first book publication, which often followed the first periodical or anthology publication by some time; we have listed the actual year of publication, often different from that given on the titlepage. No attempt has been made to indicate which works were published anonymously or pseudonymously, or which works of fiction were published in more than one volume. We have listed plays which were produced but not published, but only since 1700 ; librettos and musical plays are listed along with the other plays; no attempt has been made to list lost or unverified plays. Reprints of books (including facsimile editions) and revivals of plays are not listed unless a revision or change of title is involved. The most recent edited version of individual works is included if it supersedes the collected edition cited.

In the essays, short references to critical remarks refer to items cited in the Publications section or in the Reading List. Introductions, memoirs, editorial matter, etc. in works cited in the Publications section are not repeated in the Reading List. 